\title{
The Effect of Unemployment Benefits and Nonemployment Durations on Wages
}

\section{ONLINE APPENDIX}

\author{
Johannes F. Schmieder ${ }^{\dagger}$ \\ Boston University \\ NBER, and IZA
}

\author{
Till von Wachter \\ University of California Los Angeles, \\ NBER, CEPR, and IZA
}

Stefan Bender ${ }^{\S}$

Deutsche Bundesbank

September 2015

\footnotetext{
† Mailing Address: 270 Bay State Road, Boston, MA 02115, USA; Email: johannes@bu.edu

* Mailing Address: 8283 Bunche Hall, Los Angeles, CA 90095, USA; Email: tvwachter@econ.ucla.edu

$\S$ Mailing Address: Mainzer Landstrasse 16, 60325 Frankfurt, Germany; Email: stefan.bender@bundesbank.de
} 


\section{Contents}

\begin{tabular}{llr}
\hline 1 & Robustness Analysis & 2
\end{tabular}

2 Model Details $\quad 3$

2.1 Optimal Reservation Wage and Search Intensity Paths . . . . . . . . . . . . . . 3

2.2 Derivation of Equation (7) in main text . . . . . . . . . . . . . . 5

2.3 Proof of Proposition 1 . . . . . . . . . . . . . . . . . . 7

2.4 Bounds on the Causal Effect of Nonemployment Duration on Wages with Binding Reservation Wage . . . . . . . . . . . . . . . . . . 7

\begin{tabular}{|lll}
3 & Empirical Implementation & 9
\end{tabular}

$3.1 \quad$ Upward Bias in Wage Regression . . . . . . . . . . . . . . . . . . . . 9

\section{List of Tables}

A-1 Smoothness of Predetermined Variables around Age Thresholds . . . . . . . . . 11

A-2 The Effect of Potential UI Durations on Wages controlling for Observables _ . . . 12

A-3 The Effect of Potential UI Durations on Non-employment Durations and Wages by Sub-groups . . . . . . . . . . . . . . . . . . . . 13

A-4 Sensitivity Analysis . . . . . . . . . . . . . . . . . . . . . 14

A-5 Slope of Mean Wage Offers as Function of $\frac{d V u / d t}{d V u / d P}$ and the effect of UI extensions conditional on duration of nonemployment $d E[w \mid t] / d P \ldots \ldots \ldots \ldots$

A-6 The Effect of UI Extensions by Different States of the Business Cycle . . . . . . . 16

A-7 $\quad$ Investigating Different Channels of Wage Losses $\ldots \ldots$. . . . . . . . . . . . 17

\section{List of Figures}

A-1 Quantile Regressions of the Effects of Extended Potential UI Durations on Reemployment Wages throughout the Spell of Non-employment . . . . . . . . . . . 18 


\section{Robustness Analysis}

Our main results are all based on a two-year bandwidth around the age thresholds with linear age controls. Focusing on the model pooling both thresholds, Table A-4 shows the sensitivity of our results when we allow for more flexibility in the estimation, focusing on five outcome variables. Columns (2) and (3) show the estimated effects when the bandwidth is reduced to 1 year and 0.5 years. While the sample size drops dramatically and the standard errors increase correspondingly, the point estimates all become larger in absolute terms, pointing to worse match outcomes than in the baseline estimates. This pattern is very similar when we control for age with quadratic or cubic polynomials on both sides of the cutoff (columns 3 and 4), where the point estimates are similar to the linear specification with 0.5 years of bandwidth. Using the Calonico et al. (forthcoming) optimal bandwidth algorithm - column (5) - we obtain optimal bandwidths between 0.6 to 0.7 and again slightly more negative wage effecs.

In section 2 in the paper, we reported that we found a slight increase in density just to right of the two age thresholds. Furthermore, we found a small increase in the fraction of female UI recipients at the threshold. Here, we provide several methods to investigate whether this increase will affect our results. Column (6) of Table A-4 shows the results from estimating the marginal effect of potential benefit durations on employment outcomes using our RD design pooling both thresholds, when we exclude all observations within one month of the age threshold. Overall, while excluding the observations close to the cutoff reduces statistical power somewhat, it does not affect our overall conclusions. Column (7) of Table A-4 shows another method robustness check to limit the effect of selective waiting before claiming UI, where we limit the sample to individuals who claim UI within two weeks of losing their job. These effects are quite similar to our baseline results.

In Section 4, we had said that part of the effect on reemployment wages at the exhaustion points month 12 and month 18 are likely to be due to a change in sample composition. In particular, there is a rise in the fraction of women to the right of the RD cutoffs, and a rise in the fraction of women exiting at the exhaustion points. To address this point, we have replicated our main RD analysis and our analysis of reemployment wages by gender. While women's nonemployment durations clearly respond more strongly to UI extensions (Schmieder, von Wachter, and Bender 2012a), there is no precisely estimated difference in the effect on reemployment wages by gender. As a result, the implied IV estimate of the effect of nonemployment durations on wages is somewhat smaller for women, and approximately the same for men. Hence, our main findings are robust for the small degree of selection of women into nonemployment and UI exhaustion we find.

Another potential concern is that our main analysis focuses on workers with comparatively high labor force attachment for whom nonemployment spells might be particularly costly. As 
discussed in Section 2, we can replicate our IV strategy for any worker eligible for UI. For this broader sample, Table ?? shows we obtain a somewhat larger estimate of $-1.2 \%$ for the age 42 cutoff, and $-1.5 \%$ when we pool both cutoffs, where only the latter is statistically significant from our main sample..$^{1}$ Thus, our findings are not driven by the particular sample we use, and hold for a broad sample of middle aged workers in Germany. We also considered the effect of UI durations and nonemployment durations on wages for other subgroups, but statistical precision was low and hence did not pursue this further. ${ }^{2}$

\section{Model Details}

\subsection{Optimal Reservation Wage and Search Intensity Paths}

In the following we omit individual $i$ subscripts from the model parameters to simplify notations.

Employment is an absorbing state, i.e. once employed a worker does not get laid off or move to better jobs. Since workers discount the future at the common subjective discount rate $\rho$, the value of being employed $V^{e}$ satisfies:

$$
V^{e}\left(w^{*}\right)=\frac{1}{\rho} w^{*}
$$

The Bellman equation for an unemployed worker is given as:

$$
\begin{aligned}
V^{u}(t)=b_{t}+ & \max _{\lambda_{t}}\left[-\psi\left(\lambda_{t}\right)+\left(1-\lambda_{t}\right) \frac{1}{1+\rho} V^{u}(t+1)\right. \\
& \left.+\lambda_{t} \frac{1}{1+\rho} \int_{w} \max _{\text {accept }, \text { reject }}\left[V^{e}\left(w^{*}\right), V^{u}(t+1)\right] d F_{t}\left(w^{*}\right)\right]
\end{aligned}
$$

Since $V^{e}\left(w^{*}\right)$ is increasing in $w^{*}$, the optimal search behavior of the worker is described by a reservation wage $\phi_{t}$, so that all wage offers $w^{*} \geq \phi_{t}$ are accepted. This allows for writing the Bellman equation as:

$$
V^{u}(t)=b_{t}+\max _{\lambda_{t}}\left[-\psi\left(\lambda_{t}\right)+\frac{1}{1+\rho}\left(V^{u}(t+1)+\lambda_{t} \int_{\phi_{t}}^{\infty} V^{e}\left(w^{*}\right)-V^{u}(t+1) d F_{t}\left(w^{*}\right)\right)\right]
$$

Suppose that the environment becomes stationary for some $t \geq T$. In particular UI benefits and the wage offer distribution become constant after $T: b_{t}=b, F_{t}\left(w^{*}\right)=F_{T}\left(w^{*}\right)$. This implies that the optimal search strategy is a constant: reservation wage $\phi_{T}$. Using the fact that $V^{u}(t)=V^{u}(t+1)$ in

\footnotetext{
${ }^{1}$ The difference in the size of the IV estimate is mainly driven by a smaller effect of UI extensions on nonemployment durations, which is to be expected since the average rise of potential UI durations is smaller for this group.

${ }^{2}$ For example, while lower educated workers had substantially larger responses in employment duration, the effect of UI durations on wage changes appeared only slightly larger for the lower educated, implying a smaller (but not precisely estimated) causal effect of nonemployment durations on wages.
} 
the stationary environment, it follows that the stationary reservation wage and the optimal search intensity are given by the follwowing system of equations:

$$
\begin{gathered}
\phi_{T}=(1+\rho)\left(b_{T}-\psi\left(\lambda_{T}\right)\right)+\frac{\lambda_{T}}{\rho} \int_{\phi_{T}}^{\infty} w^{*}-\phi_{T} d F_{T}\left(w^{*}\right) \\
(1+\rho) \rho \psi^{\prime}\left(\lambda_{T}\right)-\int_{\phi_{T}}^{\infty} w^{*}-\phi_{T} d F_{T}\left(w^{*}\right)=0
\end{gathered}
$$

An optimal search strategy in this model is described by a reservation wage $\phi_{t}$ and search intensity $\lambda_{t}$ in each period. In the appendix we show that the optimal reservation wage and search intensity paths are described by the following pair of difference equations, where the reservation wage and search intensity in period $t-1$ can be derived from the reservatoin wage in period $t$.

In the nonstationary environment, $t<T$, we use the fact that: $\frac{1}{\rho} \phi_{t}=V^{u}(t+1)$. Therefore knowledge about the reservation wage $\phi_{t}$ and the optimal search intensity $\lambda_{t}$ in period $t$ will allow us to find the reservation wage in period $t-1$ using this equation:

$$
(1+\rho) \phi_{t-1}=(1+\rho) \rho\left(b_{t-1}-\psi\left(\lambda_{t}\right)\right)+\phi_{t}+\lambda_{t} \int_{\phi_{t}}^{\infty} w^{*}-\phi_{t} d F_{t}\left(w^{*}\right)
$$

Once we have found the reservation wage $\phi_{t-1}$ in period $t-1$ we can directly solve for the optimal search intensity in the same period:

$$
(1+\rho) \rho \psi^{\prime}\left(\lambda_{t-1}\right)-\int_{\phi_{t-1}}^{\infty} w^{*}-\phi_{t-1} d F_{t}\left(w^{*}\right)=0
$$

In our empirical application we consider a system where UI benefits are at a constant level $b$ up to the maximum potential duration of receiving UI benefits $P$. After benefit exhaustion, indivduals receive a second tier of payments indefinitely. We therefore have that $b_{t}=b$ for all $t \leq P$ and $b_{t}=\underline{b}$ for all $t>P$. Consider how the reservation wage path and the search intensity path is affected by a change in potential UI durations $P$. Using the first order conditions we get that:

$$
\frac{d \phi_{t}}{d P}=\frac{d V_{t+1}^{u}}{d P} \rho
$$

and

$$
\frac{d \lambda_{t}}{d P}=-\frac{d V_{t+1}^{u}}{d P} \frac{1-F_{t}\left(\phi_{t}\right)}{(1+\rho) \psi^{\prime \prime}\left(\lambda_{t}\right)}
$$

If there is at least a small chance that individuals might not find a job until UI exhaustion at $t=P$, then increasing $P$ will increase the value of remaining unemployed for all $t \leq P$, so that $\frac{d V_{t+1}^{u}}{d P}>0$. Therefore increasing $P$ will increase the reservation wage $\phi_{t}$ and lower search intensity 
$\lambda_{t}$

Since the hazard of leaving unemployment is given as $h_{t}=\lambda_{t}\left(1-F_{t}\left(\phi_{t}\right)\right)$, we get that

$$
\frac{d h_{t}}{d P}=-\frac{d V_{t+1}^{u}}{d P}\left[\frac{\left(1-F_{t}\left(\phi_{t}\right)\right)^{2}}{(1+\rho) \psi^{\prime \prime}\left(\lambda_{t}\right)}+\rho \lambda_{t} f\left(\phi_{t}\right)\right]
$$

Therefore if the extension in UI benefits affects the value of being unemployed in period $t$, then it will lower the probability of leaving unemployment in that period.

\subsection{Derivation of Equation (7) in main text}

The expected reemployment wage of individual $i$ conditional on $t$ is given as:

$$
w_{i}^{e}(t, P)=E\left[w\left(t_{i}, P, \zeta_{i}, u\right) \mid t_{i}, \zeta_{i}\right]=\frac{\int_{\phi_{t}}^{\infty} w^{*} d F_{t}\left(w^{*}\right)}{1-F_{t}\left(\phi_{t}\right)}
$$

Individual unemployment duration $t_{i}=t\left(P, \zeta_{i}, \varepsilon\right)$ is equal to the first period when a job offer arrives with a wage above the reservation wage. Thus $\varepsilon$ is a vector of indicators signifying whether for each period there is a job offer with a wage above the reservation wage: $\varepsilon=\left\{I\left[j_{o b} \_f f e r_{t}\right] \times\right.$ $\left.I\left[w * \geq \phi_{t}\right]\right\}$ for $t=0,1, \ldots$ Note that the realized $\varepsilon$ does not contain information about the value realized of realized wage offers conditional on being above the reservation wage.

We denote the distribution of $\varepsilon$ for an individual with parameters $\zeta_{i}$ as $d H\left(\varepsilon ; \zeta_{i}\right)$ and therefore the expected unemployment duration of an individual is: $t_{i}^{e}\left(P, \zeta_{i}\right)=\int t\left(P, \zeta_{i}, \varepsilon\right) d H\left(\varepsilon ; \zeta_{i}\right)$

The expected reemployment wage of individual $i$ (not conditioning on unemployment duration) $w_{i}^{e}(P)=E\left[w_{i}^{e}(t, P) \mid \zeta_{i}\right]$ can be obtained by integrating over $H\left(t ; \zeta_{i}\right)$ :

$$
w_{i}^{e}(P)=E\left[w\left(t_{i}, P, \zeta_{i}, u\right) \mid \zeta_{i}\right]=\int w_{i}^{e}(t, P) d H\left(\varepsilon ; \zeta_{i}\right)
$$

The expected reemployment wage in population conditional on $t, w^{e}(t, P)=E\left[w_{i}^{e}(t, P) \mid t\right]$ is obtained by integrating over the distribution of $\zeta_{i}$ :

$$
w^{e}(t, P)=E\left[w\left(t_{i}, P, \zeta_{i}, u\right) \mid t\right]=\int w_{i}^{e}(t, P) d G\left(\zeta_{i}\right)
$$

The expected unconditional reemployment wage $w^{e}(P)=E\left[w_{i}^{e}(t, P)\right]=E\left[w_{i}^{e}(P)\right]=E\left[w^{e}(t, P)\right]$ can then be obtained by integrating over durations $t$ and parameters $\zeta_{i}$

$$
w^{e}(P)=E\left[w\left(t_{i}, P, \zeta_{i}, u\right)\right]=\iint w_{i}^{e}(t, P) d H\left(\varepsilon ; \zeta_{i}\right) d G\left(\zeta_{i}\right)
$$


Now we have that:

$$
\begin{aligned}
w^{e}(P+h)-w^{e}(P) & =E\left[w_{i}^{e}(t(P+h), P+h)-w_{i}^{e}(t(P), P)\right] \\
& =E\left[w_{i}^{e}(t(P+h), P+h)-w_{i}^{e}(t(P+h), P)+w_{i}^{e}(t(P+h), P)-w_{i}^{e}(t(P), P)\right] \\
& =E\left[w_{i}^{e}(t(P+h), P+h)-w_{i}^{e}(t(P+h), P)\right]+E\left[w_{i}^{e}(t(P+h), P)-w_{i}^{e}(t(P), P)\right]
\end{aligned}
$$

Consider the second part of this expression:

$$
\begin{aligned}
E\left[w_{i}^{e}\left(t_{i}(P+h), P\right)-w_{i}^{e}\left(t_{i}(P), P\right)\right] & =E\left[\int_{t_{i}(P, \varepsilon)}^{t_{i}(P+h, \varepsilon)} \frac{\partial w_{i}^{e}}{\partial t}(t) d t\right] \\
& =E\left[\int_{0}^{\infty} \frac{\partial w_{i}^{e}}{\partial t}(t) \times I\left(t_{i}(P, \varepsilon)<t<t_{i}(P+h, \varepsilon)\right) d t\right] \\
& =\iiint_{0}^{\infty} \frac{\partial w_{i}^{e}}{\partial t}(t) \times I\left(t_{i}(P, \varepsilon)<t<t_{i}(P+h, \varepsilon)\right) d t d H\left(\varepsilon ; \zeta_{i}\right) d G\left(\zeta_{i}\right) \\
& =\int_{0}^{\infty} \iint \frac{\partial w_{i}^{e}}{\partial t}(t) \times I\left(t_{i}(P, \varepsilon)<t<t_{i}(P+h, \varepsilon)\right) d H\left(\varepsilon ; \zeta_{i}\right) d G\left(\zeta_{i}\right) d t \\
& =\int_{0}^{\infty} \int \frac{\partial w_{i}^{e}}{\partial t}(t) \times \int I\left(t_{i}(P, \varepsilon)<t<t_{i}(P+h, \varepsilon)\right) d H\left(\varepsilon ; \zeta_{i}\right) d G\left(\zeta_{i}\right) d t \\
& =\int_{0}^{\infty} \int \frac{\partial w_{i}^{e}}{\partial t}(t) \times I\left(t_{i}^{e}(P)<t<t_{i}^{e}(P+h)\right) d G\left(\zeta_{i}\right) d t \\
& =\int_{0}^{\infty} E_{\zeta}\left[\frac{\partial w_{i}^{e}(t)}{\partial t} \times I\left(t_{i}^{e}(P)<t<t_{i}^{e}(P+h)\right)\right] d t \\
& =\int_{0}^{\infty} E_{\zeta}\left[\frac{\partial w_{i}^{e}(t)}{\partial t} \mid t, t_{i}^{e}(P)<t<t_{i}^{e}(P+h)\right] \operatorname{Pr}\left(t_{i}^{e}(P)<t<t_{i}^{e}(P+h)\right) d t(9)
\end{aligned}
$$

Note that

$$
\begin{aligned}
\operatorname{Pr}\left(t_{i}^{e}(P)<t<t_{i}^{e}(P+h)\right) & =\operatorname{Pr}\left(t<t_{i}^{e}(P+h)\right)-\operatorname{Pr}\left(t<t_{i}^{e}(P)\right) \\
& =S(t ; P+h))-S(t ; P))
\end{aligned}
$$

Taking the limit of equation (9) for $h \rightarrow 0$, we get that:

$$
\begin{aligned}
\lim _{h \rightarrow 0} \frac{E\left[w_{i}\left(t_{i}(P+h), P\right)-w_{i}\left(t_{i}(P)\right), P\right]}{h} & =\lim _{h \rightarrow 0} \frac{\int_{0}^{\infty} E_{\zeta}\left[\frac{\partial w_{i}^{e}(t)}{\partial t} \mid t_{i}^{e}(P)<t<t_{i}^{e}(P+h)\right] \operatorname{Pr}\left(t_{i}^{e}(P)<t<t_{i}^{e}(P+h)\right) d t}{h} \\
& =\int_{0}^{\infty} \lim _{h \rightarrow 0} \frac{E_{\zeta}\left[\frac{\partial w_{i}^{e}(t)}{\partial t} \mid t_{i}^{e}(P)<t<t_{i}^{e}(P+h)\right] \operatorname{Pr}\left(t_{i}^{e}(P)<t<t_{i}^{e}(P+h)\right)}{h} d t \\
& =\int_{0}^{\infty} \lim _{h \rightarrow 0} \frac{E_{\zeta}\left[\frac{\partial w_{i}^{e}(t)}{\partial t} \mid t_{i}^{e}(P)<t<t_{i}^{e}(P+h)\right]}{h} \times \lim _{h \rightarrow 0} \frac{\operatorname{Pr}\left(t_{i}^{e}(P)<t<t_{i}^{e}(P+h)\right)}{h} d t \\
& =\int_{0}^{\infty} E_{\zeta}\left[\frac{\partial w_{i}^{e}(t)}{\partial t} \mid \frac{\partial S_{i}(t)}{\partial P}>0\right] \frac{\partial S(t)}{\partial P} d t
\end{aligned}
$$

Now we take the limit of equation $(8)$ for $h \rightarrow 0$, to obtain the derivative 


$$
\begin{aligned}
\frac{d E\left[w_{i}^{e}\left(t_{i}, P, \zeta_{i}, u\right)\right]}{d P} & =\lim _{h \rightarrow 0} \frac{w^{e}(P+h)-w^{e}(P)}{h} \\
& =E\left[\frac{\partial w_{i}^{e}(t, P)}{\partial P}\right]+\int_{0}^{\infty} E_{\zeta}\left[\frac{\partial w_{i}^{e}(t)}{\partial t} \mid \frac{\partial S_{i}(t)}{\partial P}>0\right] \frac{\partial S(t)}{\partial P} d t
\end{aligned}
$$

q.e.d.

\subsection{Proof of Proposition 1}

Suppose $\frac{\partial w_{i}^{e}(t, P)}{\partial \phi_{i t}}=0$ for all individuals who respond to changes in UI durations. It then follows that $E\left[\frac{\partial w_{i}^{e}(t, P)}{\partial P}\right]=0$ or equivalently that the first term in equation (8) in this appendix is equal to zero. Furthermore $\frac{\partial w_{i}^{e}(t, P)}{\partial \phi_{i t}}=0$ implies that $\frac{\partial w_{i}^{e}(t)}{\partial t}=\frac{\partial w_{i}^{e}\left(\phi_{i t}, \mu_{i t}\right)}{\partial \mu_{i t}} \frac{\partial \mu_{i t}}{\partial t}$. Plugging this into equation (9) above, directly yields the result in Proposition 1.

\subsection{Bounds on the Causal Effect of Nonemployment Duration on Wages with Binding Reser- vation Wage}

\section{Linear homogeneous case}

Here we show how the causal effect of nonemployment durations on wages can be calculated for the homogenous-linear case. We have that $\frac{\partial w^{e}(t, P)}{\partial P}=\frac{\partial w^{e}(t, P)}{\partial \phi_{t}} \frac{\partial \phi_{t}}{\partial P}=\frac{\partial w^{e}(t, P)}{\partial \phi_{t}} \frac{d V_{t}^{u}}{d P} \rho$ and therefore: $\frac{\partial w^{e}(t, P)}{\partial \phi_{t}}=\frac{\frac{\partial w^{e}(t, P)}{\partial P}}{\frac{d V_{t}^{u}}{d P} \rho}$. To simplify notation denote: $\delta=E\left[\frac{\partial w^{e}(t, P)}{\partial P}\right]$ and note that in the linear case: $E\left[\frac{\partial w^{e}(t, P)}{\partial P}\right]=\frac{\partial w^{e}(t, P)}{\partial P}$. Plugging this into equation (5) in the main text we get:

$$
\begin{aligned}
\frac{d E\left[w^{e}(t ; P)\right]}{d P} & =\delta+\left[\delta\left(\frac{d V_{t}^{u}}{d P} \rho\right)^{-1} \frac{\partial \phi_{t}}{\partial t}+\frac{\partial w^{e}(t ; P)}{\partial \mu_{t}} \frac{\partial \mu_{t}}{\partial t}\right] \frac{d D}{d P} \\
& =\delta+\left[\delta \frac{\frac{d V_{t}^{u}}{d t}}{\frac{d V_{t}^{u}}{d P}}+\frac{\partial w^{e}(t ; P)}{\partial \mu_{t}} \frac{\partial \mu_{t}}{\partial t}\right] \frac{d D}{d P}
\end{aligned}
$$

where we use that the change in the reservation wage from one period to the next is proportional to the change in the value of unemployment: $\frac{\partial \phi_{t}}{\partial t}=\frac{d V_{t}^{u}}{d t} \rho$. Some rearranging yields the slope of the wage offer distribution as a function of the IV estimator from above plus a term that depends on $\delta$ and the ratio of the change in the value of unemployment over time, relative to the change in the value of unemployment when potential UI benefits are extended by one month:

$$
\frac{\partial w^{e}(t ; P)}{\partial \mu_{t}} \frac{\partial \mu_{t}}{\partial t}=\frac{\frac{d E\left[w^{e}(t ; P)\right]}{d P}}{\frac{d D}{d P}}-\delta\left[\frac{1}{\frac{d D}{d P}}+\frac{\frac{d V_{t}^{u}}{d t}}{\frac{d V_{t}^{u}}{d P}}\right]
$$




\section{Non-linear case with heterogeneity}

Based on equation (11) above, we get:

$$
\frac{d E\left[w_{i}^{e}\left(t_{i}, P\right)\right]}{d P}=E\left[\frac{\partial w_{i}^{e}(t, P)}{\partial P}\right]+\int_{0}^{\infty} E_{i}\left[\frac{\partial w_{i}^{e}(t, P)}{\partial \phi_{i t}} \frac{\partial \phi_{i t}}{\partial t}+\frac{\partial w_{i}^{e}(t ; P)}{\partial \mu_{i t}} \frac{\partial \mu_{i t}}{\partial t} \mid \frac{\partial S_{i}(t)}{\partial P}>0\right] \frac{\partial S(t)}{\partial P} d t
$$

Using the same step as in the linear homegeneous case we can write this as:

$$
\begin{aligned}
\frac{d E\left[w_{i}^{e}\left(t_{i}, P\right)\right]}{d P}= & E\left[\frac{\partial w_{i}^{e}(t, P)}{\partial P}\right]+\int_{0}^{\infty} E_{i}\left[\frac{\frac{\partial w_{i}^{e}(t, P)}{\partial P}}{\frac{d V_{i t}^{u}}{d P}} \frac{\partial \phi_{i t}}{\partial t}+\frac{\partial w_{i}^{e}(t ; P)}{\partial \mu_{i t}} \frac{\partial \mu_{i t}}{\partial t} \mid \frac{\partial S_{i}(t)}{\partial P}>0\right] \frac{\partial S(t)}{\partial P} d t \\
= & E\left[\frac{\partial w_{i}^{e}(t, P)}{\partial P}\right]+\int_{0}^{\infty} E_{i}\left[\frac{\partial w_{i}^{e}(t, P)}{\partial P} \frac{\frac{d V_{i t}^{u}}{d t}}{\frac{d V_{i t}^{u}}{d P}}+\frac{\partial w_{i}^{e}(t ; P)}{\partial \mu_{i t}} \frac{\partial \mu_{i t}}{\partial t} \mid \frac{\partial S_{i}(t)}{\partial P}>0\right] \frac{\partial S(t)}{\partial P} d t \\
= & E\left[\frac{\partial w_{i}^{e}(t, P)}{\partial P}\right]+\int_{0}^{\infty} E_{i}\left[\frac{\partial w_{i}^{e}(t, P)}{\partial P} \frac{\frac{d V_{i t}^{u}}{d t}}{\frac{d V_{i t}^{u}}{d P}} \mid \frac{\partial S_{i}(t)}{\partial P}>0\right] \frac{\partial S(t)}{\partial P} d t \\
& +\int_{0}^{\infty} E_{i}\left[\frac{\partial w_{i}^{e}(t ; P)}{\partial \mu_{i t}} \frac{\partial \mu_{i t}}{\partial t} \mid \frac{\partial S_{i}(t)}{\partial P}>0\right] \frac{\partial S(t)}{\partial P} d t
\end{aligned}
$$

We use the notation that: $E_{i, S}[]=.\int_{0}^{\infty} E_{i}\left[. \mid \frac{\partial S_{i}(t)}{\partial P}>0\right] \frac{\frac{\partial S(t)}{\partial P}}{\frac{d D}{d P}} d t$, that is the operator $E_{i, S}[$.$] indi-$ cates taking expectation over individual heterogeneity and over non-employment durations, weighted by the shift in the survivor function. Furthermore let $\delta=E\left[\frac{\partial w_{i}^{e}(t, P)}{\partial P}\right]$, then we get:

$$
\frac{d E\left[w_{i}^{e}\left(t_{i}, P\right)\right]}{d P}=\delta+E_{i, S}\left[\frac{\partial w_{i}^{e}(t, P)}{\partial P} \frac{\frac{d V_{i t}^{u}}{d t}}{\frac{d V_{i t}^{u}}{d P}}\right] \frac{d D}{d P}+E_{i, S}\left[\frac{\partial w_{i}^{e}(t ; P)}{\partial \mu_{i t}} \frac{\partial \mu_{i t}}{\partial t}\right] \frac{d D}{d P}
$$

Therefore the IV estimator can be used to bound the weighted average of the effect of nonemployment durations on wages $E_{i, S}\left[\frac{\partial w_{i}^{e}(t ; P)}{\partial \mu_{i t}} \frac{\partial \mu_{i t}}{\partial t}\right]$, similar to equation 12 for the linear homogeneous case:

$$
\begin{gathered}
E_{i, S}\left[\frac{\partial w_{i}^{e}(t ; P)}{\partial \mu_{i t}} \frac{\partial \mu_{i t}}{\partial t}\right]=\frac{\frac{d E\left[w_{i}^{e}\left(t_{i}, P\right)\right]}{d P}}{\frac{d D}{d P}}-\delta \frac{1}{\frac{d D}{d P}}-E_{i, S}\left[\frac{\left.\partial w_{i}^{e}(t, P) \frac{\frac{d V_{i t}^{u}}{d P}}{\frac{d t}{d P}}\right]}{d P}\right] \\
\Leftrightarrow E_{i, S}\left[\frac{\partial w_{i}^{e}(t ; P)}{\partial \mu_{i t}} \frac{\partial \mu_{i t}}{\partial t}\right]=\frac{\frac{d E\left[w_{i}^{e}\left(t_{i}, P\right)\right]}{d P}}{\frac{d D}{d P}}-\delta\left(\frac{1}{\frac{d D}{d P}}+E_{i, S}\left[\frac{\frac{d V_{i t}^{u}}{d t}}{\frac{d V_{i t}^{u}}{d P}}\right]\right)-\operatorname{cov}_{i, S}\left(\frac{\partial w_{i}^{e}(t, P)}{\partial P}, \frac{\frac{d V_{i t}^{u}}{d t}}{\frac{d V_{i t}^{u}}{d P}}\right)
\end{gathered}
$$

This suggests that the intuition from the linear homogeneous case essentially carries through, as long as the covariance between $\frac{\partial w_{i}^{e}(t, P)}{\partial P}$ and $\frac{\frac{d V_{i t}^{u}}{d t}}{\frac{d V_{i t}^{u}}{d P}}$ is numerically small or positive. If the reservation wage is binding, then the covariance term is likely to be negative (because a rise in $P$ would lead 
to an increase in the reemployment wage conditional on time $t\left(w_{i}^{e}(t, P)\right)$ and on the reservation wage $\phi_{i t}$, and thus $\frac{d V_{i t}^{u}}{d P}$ ). However, if the reservation wage is not or on only weakly binding, then the reemployment wage will only change little while the ratio will decline, leading to a low covariance. This reinforces the result that the IV estimate is likely an upper bound of the (negative) effect on nonemployment duration on reemployment wages as long as reservation wages do not have a strong effect on reemployment wages. A numerically small negative covariance would tend to imply our calculated bounds are too wide.

\section{Empirical Implementation}

\subsection{Upward Bias in Wage Regression}

Consider first the case in which the effect of potential UI durations on wages is the same at all nonemployment durations, and which the effect of nonemployment durations on wages is linear. We are interested in an estimate of the coefficient $\delta$ in the linear model

$$
w_{i}^{*}=\alpha+\delta P_{i}+\theta t_{i}+u_{i}
$$

where $w=$ wage, $P=$ potential UI durations, $t=$ actual nonemployment durations. This is a linear version of equation (9) in the main text, where we have dropped the low-order polynomial in age for simplicity. Instead, we assume directly that we have that $\operatorname{cov}(P, u)=0$ and $E[u]=0$. Moreover, we know that $\operatorname{cov}(P, t) \neq 0$ and suspect that $\operatorname{cov}(t, u) \neq 0$. In matrix notation, the OLS coefficient for $\delta$ from the short regression is

$$
\hat{\delta}=\frac{P^{\prime} M_{t} w}{P^{\prime} M_{t} P}=\frac{\left(M_{t} P\right)^{\prime} M_{t} w}{P^{\prime} M_{t} P},
$$

where $M_{x} \equiv 1-P_{x}=1-x\left(x^{\prime} x\right)^{-1} x^{\prime}$ is the orthogonal projector onto the space orthogonal to $x$, and $P_{x}$ is the orthogonal projector onto the space of $x$.

The numerator of the expression for the OLS estimator for $\delta$ is what is important. Since we have $M_{t} w=\delta M_{t} P+M_{t} u$, we have that

$$
\left(M_{t} P\right)^{\prime} M_{t} w=\delta P^{\prime} M_{t} P+P^{\prime} M_{t} u
$$

where the omitted variable bias term can be rewritten as $P^{\prime} M_{t} u=P^{\prime} u-P^{\prime} P_{t} u=-P^{\prime} P_{t} u=-\left(P_{t} P\right)^{\prime} P_{t} u$, where we used the fact that $\operatorname{cov}(P, u)=E[P u] \approx P^{\prime} u / N=0$ given that $E[u]=0$. As a result we get

$$
\hat{\delta}=\frac{P^{\prime} M_{t} w}{P^{\prime} M_{t} P}=\delta+\frac{-P^{\prime} P_{t} u}{P^{\prime} M_{t} P}
$$


Since $P$ is uncorrelated with $u$, the second term in this expression can only be zero if there is no endogeneity, i.e., if $\operatorname{cov}(u, t)=0$. (This is the intution behind the test for endogeneity by Davidson and McKinnon, which tests the null hypothesis that the coefficient on the instrument when directly included in the 'structural' regression is zero, where $\delta$ would be equal to zero in a standard IV setting). This implies that if nonemployment durations are endogenous, we cannot directly estimate the average shift of the reemployment wage path from our data.

However, it turns out that with reasonable assumptions we can bound the true $\delta$. To see this, note that $P^{\prime} P_{t} u=\left(P^{\prime} t\right)\left(t^{\prime} t\right)^{-1}\left(t^{\prime} u\right)$. The first product is simply the sum of nonemployment durations for those above the age cutoff, and hence strictly greater zero. The middle term is also strictly greater zero. In contrast, we have that $\operatorname{cov}(u, t)=E(u t)=t^{\prime} u / N$. Hence, under the reasonable assumption that $t^{\prime} u \leq 0$, i.e., on average workers with lower earnings potential have longer nonemployment spells, we obtain that that $\hat{\delta}$ is an upper bound for the true $\delta$. Since from the theory, we expect that $\delta \geq 0$, a finding that $\hat{\delta} \approx 0$ implies that both $\delta \approx 0$ and $P^{\prime} P_{t} u \approx 0$. 
Table A-1: Smoothness of Predetermined Variables around Age Thresholds

\begin{tabular}{|c|c|c|c|c|c|c|c|c|}
\hline & $\begin{array}{c}(1) \\
\text { Years of } \\
\text { Education }\end{array}$ & $\begin{array}{c}(2) \\
\text { Female }\end{array}$ & $\begin{array}{c}(3) \\
\text { Foreign } \\
\text { Citizen }\end{array}$ & $\begin{array}{c}(4) \\
\text { Tenure } \\
\text { Last Job }\end{array}$ & $\begin{array}{c}(5) \\
\text { Experience } \\
\text { Last Job }\end{array}$ & $\begin{array}{c}(6) \\
\text { Pre } \\
\text { Wage }\end{array}$ & $\begin{array}{l}\text { (7) } \\
\text { UR at start } \\
\text { of unemp }\end{array}$ & $\begin{array}{c}\text { (8) } \\
\text { County UR at } \\
\text { start of unemp }\end{array}$ \\
\hline \multicolumn{9}{|c|}{ Increase in Potential UI Dur. from 12 to 18 Months } \\
\hline $\mathrm{D}$ (Age above Cutoff) & $\begin{array}{c}0.030 \\
{[0.014]^{*}}\end{array}$ & $\begin{array}{c}0.0086 \\
{[0.0028]^{* *}}\end{array}$ & $\begin{array}{c}0.0038 \\
{[0.0020]}\end{array}$ & $\begin{array}{c}0.044 \\
{[0.028]}\end{array}$ & $\begin{array}{c}-0.046 \\
{[0.031]}\end{array}$ & $\begin{array}{c}0.12 \\
{[0.18]}\end{array}$ & $\begin{array}{c}0.0016 \\
{[0.0087]}\end{array}$ & $\begin{array}{c}0.035 \\
{[0.025]}\end{array}$ \\
\hline Effect relative to mean & 0.0027 & 0.024 & 0.037 & 0.0082 & -0.0041 & 0.0017 & 0.00017 & 0.0033 \\
\hline Observations & 510955 & 510955 & 510955 & 510955 & 510955 & 480724 & 510955 & 441907 \\
\hline Mean of Dep. Var. & 11.0 & 0.36 & 0.10 & 5.35 & 11.1 & 70.8 & 9.29 & 10.4 \\
\hline \multicolumn{9}{|c|}{ Pooling both Thresholds (12 to 18 Months and 18 to 22 Months) } \\
\hline $\mathrm{D}$ (Age above Cutoff) & $\begin{array}{c}0.015 \\
{[0.0094]}\end{array}$ & $\begin{array}{c}0.0054 \\
{[0.0020]^{* *}}\end{array}$ & $\begin{array}{c}0.0017 \\
{[0.0017]}\end{array}$ & $\begin{array}{c}0.041 \\
{[0.023]}\end{array}$ & $\begin{array}{c}-0.034 \\
{[0.024]}\end{array}$ & $\begin{array}{c}0.12 \\
{[0.13]}\end{array}$ & $\begin{array}{c}-0.0095 \\
{[0.0066]}\end{array}$ & $\begin{array}{c}0.017 \\
{[0.019]}\end{array}$ \\
\hline Effect relative to mean & 0.0014 & 0.015 & 0.016 & 0.0072 & -0.0030 & 0.0016 & -0.0010 & 0.0016 \\
\hline Observations & 947068 & 947068 & 947068 & 947068 & 947068 & 888293 & 947068 & 829669 \\
\hline Mean of Dep. Var. & 10.9 & 0.36 & 0.11 & 5.69 & 11.6 & 71.6 & 9.31 & 10.4 \\
\hline
\end{tabular}

Notes: Standard errors clustered on day relative to cutoff level $(* \mathrm{P}<.05$, ** $\mathrm{P}<.01))$.

The sample are individuals who started receiving unemployment insurance between 1987 and 1999 within 2 years from the age thresholds. Each coefficient is from a separate regression discontinuity model with the dependent variable given in the column heading. The first panel shows the increase at the discontinuity at the age 42 threshold (where potential UI durations increase from 12 to 18 months). The second panel shows the increase at the age 44 threshold (where potential UI durations increase from 18 to 22 months). The third panel pools both thresholds. The models control for linear splines in age with different slopes on each side of the cutoff. 
Table A-2: The Effect of Potential UI Durations on Wages controlling for Observables

\begin{tabular}{|c|c|c|c|c|c|c|}
\hline & $\begin{array}{c}(1) \\
\text { Log Wage } \\
\text { Baseline }\end{array}$ & $\begin{array}{c}(2) \\
\text { Log Wage } \\
\text { Ctrls Obs }\end{array}$ & $\begin{array}{c}(3) \\
\text { Log Wage } \\
\text { Ctrls Obs }\end{array}$ & $\begin{array}{c}(4) \\
\text { Log Wage } \\
\text { Ctrls Obs }\end{array}$ & $\begin{array}{c}(5) \\
\text { Log Wage } \\
\text { Ctrls Obs }\end{array}$ & $\begin{array}{c}(6) \\
\text { Log Wage } \\
\text { Ctrls Obs }\end{array}$ \\
\hline \multicolumn{7}{|c|}{ Increase in Potential UI Dur. from 12 to 18 Months } \\
\hline $\mathrm{D}$ (Age above Cutoff) & $\begin{array}{c}-0.0078 \\
{[0.0036]^{* *}}\end{array}$ & $\begin{array}{c}-0.0075 \\
{[0.0034]^{* *}}\end{array}$ & $\begin{array}{c}-0.0073 \\
{[0.0034]^{* *}}\end{array}$ & $\begin{array}{c}-0.0072 \\
{[0.0034]^{* *}}\end{array}$ & $\begin{array}{c}-0.0073 \\
{[0.0034]^{* *}}\end{array}$ & $\begin{array}{c}-0.0072 \\
{[0.0034]^{* *}}\end{array}$ \\
\hline logprewage & & & $\begin{array}{c}0.44 \\
{[0.0037]^{* *}}\end{array}$ & $\begin{array}{c}0.44 \\
{[0.0037]^{* *}}\end{array}$ & $\begin{array}{c}0.39 \\
{[0.0038]^{* *}}\end{array}$ & $\begin{array}{c}0.39 \\
{[0.0038]^{* *}}\end{array}$ \\
\hline Female & & & $\begin{array}{c}-0.22 \\
{[0.0018]^{* *}}\end{array}$ & $\begin{array}{c}-0.22 \\
{[0.0018]^{* *}}\end{array}$ & $\begin{array}{c}-0.21 \\
{[0.0017]^{* *}}\end{array}$ & $\begin{array}{c}-0.21 \\
{[0.0017]^{* *}}\end{array}$ \\
\hline Non-German & & & & $\begin{array}{c}-0.062 \\
{[0.0025] * *}\end{array}$ & $\begin{array}{c}-0.067 \\
{[0.0025]^{* *}}\end{array}$ & $\begin{array}{c}-0.066 \\
{[0.0025]^{* *}}\end{array}$ \\
\hline Pre-unemp experience & & & & & $\begin{array}{c}0.012 \\
{[0.00015]^{* *}}\end{array}$ & $\begin{array}{c}0.012 \\
{[0.00016]^{* *}}\end{array}$ \\
\hline Pre-unemp industry tenure & & & & & $\begin{array}{c}-0.0042 \\
{[0.00014]^{* *}}\end{array}$ & $\begin{array}{c}-0.0047 \\
{[0.00016]^{* *}}\end{array}$ \\
\hline Pre-unemp occupation tenure & & & & & & $\begin{array}{c}0.00088 \\
{[0.00017]^{* *}}\end{array}$ \\
\hline Observations & 437182 & 422635 & 422635 & 422635 & 422635 & 422635 \\
\hline \multicolumn{7}{|c|}{ Pooling both Thresholds (12 to 18 Months and 18 to 22 Months) } \\
\hline D(Age above Cutoff) & $\begin{array}{c}-0.0051 \\
{[0.0024]^{*}}\end{array}$ & $\begin{array}{c}-0.0049 \\
{[0.0023]^{*}}\end{array}$ & $\begin{array}{c}-0.0051 \\
{[0.0022]^{*}}\end{array}$ & $\begin{array}{c}-0.0048 \\
{[0.0021]^{*}}\end{array}$ & $\begin{array}{c}-0.0049 \\
{[0.0021]^{*}}\end{array}$ & $\begin{array}{c}-0.0046 \\
{[0.0021]^{*}}\end{array}$ \\
\hline logprewage & & & $\begin{array}{c}0.44 \\
{[0.0027]^{* *}}\end{array}$ & $\begin{array}{c}0.44 \\
{[0.0027]^{* *}}\end{array}$ & $\begin{array}{c}0.39 \\
{[0.0028]^{* *}}\end{array}$ & $\begin{array}{c}0.39 \\
{[0.0028]^{* *}}\end{array}$ \\
\hline Female & & & $\begin{array}{c}-0.22 \\
{[0.0013]^{* *}}\end{array}$ & $\begin{array}{c}-0.22 \\
{[0.0013]^{* *}}\end{array}$ & $\begin{array}{c}-0.21 \\
{[0.0012]^{* *}}\end{array}$ & $\begin{array}{c}-0.21 \\
{[0.0012]^{* *}}\end{array}$ \\
\hline Non-German & & & & $\begin{array}{c}-0.062 \\
{[0.0018]^{* *}}\end{array}$ & $\begin{array}{c}-0.069 \\
{[0.0018]^{* *}}\end{array}$ & $\begin{array}{c}-0.068 \\
{[0.0018]^{* *}}\end{array}$ \\
\hline Pre-unemp experience & & & & & $\begin{array}{c}0.013 \\
{[0.00011]^{* *}}\end{array}$ & $\begin{array}{c}0.012 \\
{[0.00012]^{* *}}\end{array}$ \\
\hline Pre-unemp industry tenure & & & & & $\begin{array}{c}-0.0043 \\
{[0.000100]^{* *}}\end{array}$ & $\begin{array}{c}-0.0046 \\
{[0.00012]^{* *}}\end{array}$ \\
\hline Pre-unemp occupation tenure & & & & & & $\begin{array}{c}0.00063 \\
{[0.00012]^{* *}}\end{array}$ \\
\hline Observations & 797752 & 771197 & 771197 & 771197 & 771197 & 771197 \\
\hline
\end{tabular}

Notes: $* \mathrm{P}<.05, * * \mathrm{P}<.01$. Robust standard errors based on the method of Calonico et al. (2014).

Columns 2-6 control for year, state and pre-unemployment industry fixed effects. 
Table A-3: The Effect of Potential UI Durations on Non-employment Durations and Wages by Sub-groups

\begin{tabular}{|c|c|c|c|c|}
\hline & $\begin{array}{c}(1) \\
\text { UI Ben. } \\
\text { Duration }\end{array}$ & $\begin{array}{c}(2) \\
\text { Non-Emp } \\
\text { Duration }\end{array}$ & $\begin{array}{l}(3) \\
\text { Log Post } \\
\text { Wage }\end{array}$ & $\begin{array}{c}(4) \\
\text { Log Wage } \\
\text { Difference }\end{array}$ \\
\hline $\begin{array}{l}\text { Men Only } \\
\frac{d y}{d P} \\
\text { Observations }\end{array}$ & $\begin{array}{c}0.22 \\
{[0.0068]^{* *}} \\
602852\end{array}$ & $\begin{array}{c}0.097 \\
{[0.014]^{* *}} \\
602852\end{array}$ & $\begin{array}{c}-0.00084 \\
{[0.00048]} \\
517473\end{array}$ & $\begin{array}{c}-0.00094 \\
{[0.00048]^{*}} \\
498508\end{array}$ \\
\hline $\begin{array}{l}\text { Women Only } \\
\frac{d y}{d P} \\
\text { Observations }\end{array}$ & $\begin{array}{c}0.40 \\
{[0.010]^{* *}} \\
344216\end{array}$ & $\begin{array}{c}0.19 \\
{[0.020]^{* *}} \\
344216\end{array}$ & $\begin{array}{c}-0.00048 \\
{[0.00078]} \\
280279\end{array}$ & $\begin{array}{c}-0.0013 \\
{[0.00084]} \\
268653\end{array}$ \\
\hline $\begin{array}{l}\text { Education: Abitur (U } \\
\frac{d y}{d P} \\
\text { Observations }\end{array}$ & $\begin{array}{c}\text { iversity qual } \\
0.24 \\
{[0.014]^{* *}} \\
157595\end{array}$ & $\begin{array}{c}\text { exam) or h } \\
0.077 \\
{[0.028]^{* *}} \\
157595\end{array}$ & $\begin{array}{l}\text { gher } \\
\quad-0.0013 \\
{[0.0011]} \\
136822\end{array}$ & $\begin{array}{c}-0.00076 \\
{[0.0010]} \\
134099\end{array}$ \\
\hline $\begin{array}{l}\text { Effect relative to mean } \\
\text { Observations }\end{array}$ & $\begin{array}{c}\text { bitur (Univ } \\
0.30 \\
{[0.0064]^{* *}} \\
0.18 \\
789473\end{array}$ & $\begin{array}{c}\text { sity qual. } \\
0.15 \\
{[0.013]^{* *}} \\
0.049 \\
789473\end{array}$ & $\begin{array}{l}\text { xam) } \\
\quad-0.0012 \\
{[0.00044]^{* *}} \\
-0.0015 \\
660930\end{array}$ & $\begin{array}{c}-0.0012 \\
{[0.00047]^{*}} \\
0.040 \\
633062\end{array}$ \\
\hline $\begin{array}{l}\text { Years 1987-1991 } \\
\frac{d y}{d P} \\
\text { Observations }\end{array}$ & $\begin{array}{c}0.26 \\
{[0.011]^{* *}} \\
322897\end{array}$ & $\begin{array}{c}0.16 \\
{[0.022]^{* *}} \\
322897\end{array}$ & $\begin{array}{c}-0.00098 \\
{[0.00081]} \\
274427\end{array}$ & $\begin{array}{c}-0.00094 \\
{[0.00097]} \\
268938\end{array}$ \\
\hline $\begin{array}{l}\text { Years 1992-1999 } \\
\frac{d y}{d P} \\
\text { Observations }\end{array}$ & $\begin{array}{c}0.30 \\
{[0.071]^{* *}} \\
623171\end{array}$ & $\begin{array}{c}0.13 \\
{[0.016]^{* *}} \\
623171\end{array}$ & $\begin{array}{c}-0.0011 \\
{[0.00051]^{*}} \\
523325\end{array}$ & $\begin{array}{c}-0.0013 \\
{[0.00055]^{*}} \\
512859\end{array}$ \\
\hline $\begin{array}{l}\text { West Germany } \\
\frac{d y}{d P} \\
\text { Observations }\end{array}$ & $\begin{array}{c}0.26 \\
{[0.015]^{* *}} \\
145848\end{array}$ & $\begin{array}{c}0.13 \\
{[0.029]^{* *}} \\
145848\end{array}$ & $\begin{array}{c}-0.0011 \\
{[0.0011]} \\
123652\end{array}$ & $\begin{array}{c}-0.0012 \\
{[0.0011]} \\
121179\end{array}$ \\
\hline $\begin{array}{l}\text { East Germany } \\
\frac{d y}{d P} \\
\text { Observations }\end{array}$ & $\begin{array}{c}0.31 \\
{[0.0062]^{* *}} \\
801219\end{array}$ & $\begin{array}{c}0.15 \\
{[0.012]^{* *}} \\
801219\end{array}$ & $\begin{array}{c}-0.0089 \\
{[0.00042]^{* *}} \\
674100\end{array}$ & $\begin{array}{c}-0.0010 \\
{[0.00043]^{*}} \\
660618\end{array}$ \\
\hline
\end{tabular}

Notes: Coefficients from RD regressions. Local linear regressions (different slopes) on each side of cutoff. Standard errors clustered on day level $(* \mathrm{P}<.05$, ** $\mathrm{P}<.01)$ ). 
Table A-4: Sensitivity Analysis

\begin{tabular}{|c|c|c|c|c|c|c|c|}
\hline & $\begin{array}{c}\text { (1) } \\
\text { Bandwidth: } \\
1 \text { Year }\end{array}$ & $\begin{array}{c}(2) \\
\text { Bandwidth: } \\
0.5 \text { Years }\end{array}$ & $\begin{array}{c}\text { (3) } \\
\text { Quadratic } \\
\text { Age Control }\end{array}$ & $\begin{array}{c}(4) \\
\text { Cubic } \\
\text { Age Control }\end{array}$ & $\begin{array}{c}(5) \\
\text { Optimal } \\
\text { Bandwidth } \\
\text { (Calonico et al) }\end{array}$ & $\begin{array}{l}\quad(6) \\
\text { Excluding Obs } \\
\text { within } 1 \text { month } \\
\text { of threshold }\end{array}$ & $\begin{array}{l}\text { (7) } \\
\text { Sample restricted } \\
\text { to UI takeup within } \\
15 \text { days of job end }\end{array}$ \\
\hline \multicolumn{8}{|c|}{ Non-employment duration } \\
\hline$\frac{d y}{d P}$ & $\begin{array}{c}0.19 \\
{[0.034]^{* *}}\end{array}$ & $\begin{array}{c}0.23 \\
{[0.049]^{* *}}\end{array}$ & $\begin{array}{c}0.17 \\
{[0.039]^{* *}}\end{array}$ & $\begin{array}{c}0.24 \\
{[0.051]^{* *}}\end{array}$ & $\begin{array}{c}0.19 \\
{[0.041]^{* *}}\end{array}$ & $\begin{array}{c}0.12 \\
{[0.029]^{* *}}\end{array}$ & $\begin{array}{c}0.15 \\
{[0.027]^{* *}}\end{array}$ \\
\hline $\begin{array}{l}\text { Observations } \\
\text { Optimal Bandwidth }\end{array}$ & 399918 & 199889 & 799105 & 799105 & $\begin{array}{c}255851 \\
0.64\end{array}$ & 765540 & 696777 \\
\hline \multicolumn{8}{|l|}{ Log post wage } \\
\hline$\frac{d y}{d P}$ & $\begin{array}{c}-0.0020 \\
{[0.00072]^{* *}}\end{array}$ & $\begin{array}{c}-0.0019 \\
{[0.0010]^{*}}\end{array}$ & $\begin{array}{c}-0.0017 \\
{[0.00081]^{*}}\end{array}$ & $\begin{array}{c}-0.0025 \\
{[0.0012]^{*}}\end{array}$ & $\begin{array}{c}-0.0020 \\
{[0.00081]^{* *}}\end{array}$ & $\begin{array}{c}-0.00090 \\
{[0.00046]^{*}}\end{array}$ & $\begin{array}{c}-0.0012 \\
{[0.00051]^{*}}\end{array}$ \\
\hline $\begin{array}{l}\text { Observations } \\
\text { Optimal Bandwidth }\end{array}$ & 399245 & 199570 & 797752 & 797752 & $\begin{array}{c}247862 \\
0.62\end{array}$ & 764232 & 695689 \\
\hline \multicolumn{8}{|l|}{ Log wage difference } \\
\hline$\frac{d y}{d P}$ & $\begin{array}{c}-0.0020 \\
{[0.00073]^{* *}}\end{array}$ & $\begin{array}{c}-0.0025 \\
{[0.0012]^{*}}\end{array}$ & $\begin{array}{c}-0.0015 \\
{[0.00079]^{*}}\end{array}$ & $\begin{array}{c}-0.0033 \\
{[0.0012]^{* *}}\end{array}$ & $\begin{array}{c}-0.0021 \\
{[0.00082]^{* *}}\end{array}$ & $\begin{array}{l}-0.00057 \\
{[0.00060]}\end{array}$ & $\begin{array}{c}-0.0013 \\
{[0.00048]^{* *}}\end{array}$ \\
\hline $\begin{array}{l}\text { Observations } \\
\text { Optimal Bandwidth }\end{array}$ & 384054 & 191913 & 767161 & 767161 & $\begin{array}{c}267830 \\
0.67\end{array}$ & 734989 & 675826 \\
\hline \multicolumn{8}{|c|}{ Duration of post unemployment job } \\
\hline$\frac{d y}{d P}$ & $\begin{array}{c}-0.029 \\
{[0.0092]^{* *}}\end{array}$ & $\begin{array}{c}-0.027 \\
{[0.014]^{*}}\end{array}$ & $\begin{array}{c}-0.017 \\
{[0.0081]^{*}}\end{array}$ & $\begin{array}{c}-0.041 \\
{[0.013]^{* *}}\end{array}$ & $\begin{array}{c}-0.027 \\
{[0.012]^{* *}}\end{array}$ & $\begin{array}{l}-0.0066 \\
{[0.0071]}\end{array}$ & $\begin{array}{l}-0.0093 \\
{[0.0070]}\end{array}$ \\
\hline $\begin{array}{l}\text { Observations } \\
\text { Optimal Bandwidth }\end{array}$ & 356808 & 178324 & 712660 & 712660 & $\begin{array}{c}228230 \\
0.64\end{array}$ & 682711 & 622283 \\
\hline
\end{tabular}

Notes: $* \mathrm{P}<.05, * * \mathrm{P}<.01$. Robust standard errors based on the method of Calonico et al. (2014). The optimal bandwidth in column (5) is also calculated using the Calonico et al. algorithm.

The sample are individuals who started receiving unemployment insurance between 1987 and 1999. Each panel shows the increase at the age threshold of the dependent variable (given in the panel title) rescaled by the average increase in potential UI durations at the thresholds. The columns refer to different estimating the RD model with different bandwidths and controlling for different polynomials in age. 
Table A-5: Slope of Mean Wage Offers as Function of $\frac{d V u / d t}{d V u / d P}$ and the effect of UI extensions conditional on duration of nonemployment $d E[w \mid t] / d P$

\begin{tabular}{lccccccccc}
\hline & \multicolumn{7}{c}{$\frac{d V u / d t}{d V u / d P}$} \\
$\delta=E[d E[w \mid t] / d P]$ in percent & -1 & -2 & -3 & -4 & -5 & -6 & -7 & -8 & -9 \\
\hline 0 & -0.008 & -0.008 & -0.008 & -0.008 & -0.008 & -0.008 & -0.008 & -0.008 & -0.008 \\
0.095 & -0.014 & -0.013 & -0.012 & -0.011 & -0.010 & -0.009 & -0.008 & -0.007 & -0.006 \\
0.1 & -0.014 & -0.013 & -0.012 & -0.011 & -0.010 & -0.009 & -0.008 & -0.007 & -0.006 \\
0.2 & -0.020 & -0.018 & -0.016 & -0.014 & -0.012 & -0.010 & -0.008 & -0.006 & -0.004 \\
0.3 & -0.026 & -0.023 & -0.020 & -0.017 & -0.014 & -0.011 & -0.008 & -0.005 & -0.002 \\
0.4 & -0.032 & -0.028 & -0.024 & -0.020 & -0.016 & -0.012 & -0.008 & -0.004 & 0.000 \\
0.5 & -0.039 & -0.034 & -0.029 & -0.024 & -0.019 & -0.014 & -0.009 & -0.004 & 0.001 \\
0.6 & -0.045 & -0.039 & -0.033 & -0.027 & -0.021 & -0.015 & -0.009 & -0.003 & 0.003 \\
0.7 & -0.051 & -0.044 & -0.037 & -0.030 & -0.023 & -0.016 & -0.009 & -0.002 & 0.005 \\
0.8 & -0.057 & -0.049 & -0.041 & -0.033 & -0.025 & -0.017 & -0.009 & -0.001 & 0.007 \\
0.9 & -0.063 & -0.054 & -0.045 & -0.036 & -0.027 & -0.018 & -0.009 & 0.000 & 0.009 \\
1.0 & -0.069 & -0.059 & -0.049 & -0.039 & -0.029 & -0.019 & -0.009 & 0.001 & 0.011 \\
\hline
\end{tabular}

Notes: The table shows the implied slope of the mean wage offer distribution if the effect of potential UI durations on reemployment wages conditional on nonemployment durations is not equal to zero $d E[w \mid t] / d P$. Rows show the implied slope for different values of $d E[w \mid t] / d P$ and columns for different values of $\frac{d V u / d t}{d V u / d P}$. The preferred point Estimate for $d E[w \mid t] / d P$ is $0.015 \%$ (from last column and bottom panel of Table 10).

The upper bound of the $95 \%$ confidence interval for $d E[w \mid t] / d P$ is $0.095 \%$. 
Table A-6: The Effect of UI Extensions by Different States of the Business Cycle

\begin{tabular}{|c|c|c|c|c|c|c|}
\hline \multirow{3}{*}{$\begin{array}{l}\text { Increase in Potential UI } \\
\text { Dur. from } 12 \text { to } 18 \mathrm{Mon}\end{array}$} & \multicolumn{3}{|c|}{ Unemployment Rate Decreasing } & \multicolumn{3}{|c|}{ Unemployment Rate Increasing } \\
\hline & $\begin{array}{l}\text { Non-Emp } \\
\text { Duration }\end{array}$ & $\begin{array}{l}\text { Log Post } \\
\text { Wage }\end{array}$ & $\begin{array}{l}\text { Log Wage } \\
\text { Difference }\end{array}$ & $\begin{array}{l}\text { Non-Emp } \\
\text { Duration }\end{array}$ & $\begin{array}{l}\text { Log Post } \\
\text { Wage }\end{array}$ & $\begin{array}{l}\text { Log Wage } \\
\text { Difference }\end{array}$ \\
\hline & & & & & & \\
\hline D(Age above Cutoff) & $\begin{array}{c}0.97 \\
{[0.22]^{* *}}\end{array}$ & $\begin{array}{l}-0.0072 \\
{[0.0049]}\end{array}$ & $\begin{array}{l}-0.0017 \\
{[0.0046]}\end{array}$ & $\begin{array}{c}0.90 \\
{[0.17]^{* *}}\end{array}$ & $\begin{array}{c}-0.0081 \\
{[0.0037]^{*}}\end{array}$ & $\begin{array}{c}-0.0092 \\
{[0.0036]^{*}}\end{array}$ \\
\hline$\frac{d y}{d P}$ & $\begin{array}{c}0.16 \\
{[0.037]^{* *}}\end{array}$ & $\begin{array}{c}-0.0012 \\
{[0.00082]}\end{array}$ & $\begin{array}{c}-0.00028 \\
{[0.00077]}\end{array}$ & $\begin{array}{c}0.15 \\
{[0.029]^{* *}}\end{array}$ & $\begin{array}{c}-0.0013 \\
{[0.00062]^{*}}\end{array}$ & $\begin{array}{c}-0.0015 \\
{[0.00061]^{*}}\end{array}$ \\
\hline $\begin{array}{l}\text { Effect relative to mean } \\
\text { Observations }\end{array}$ & $\begin{array}{c}0.071 \\
168936\end{array}$ & $\begin{array}{l}-0.0018 \\
168637\end{array}$ & $\begin{array}{c}0.015 \\
161534\end{array}$ & $\begin{array}{c}0.059 \\
268963\end{array}$ & $\begin{array}{l}-0.0020 \\
268545\end{array}$ & $\begin{array}{c}0.059 \\
258777\end{array}$ \\
\hline Pooling both Threshold & & & & & & \\
\hline D(Age above Cutoff) & $\begin{array}{c}0.62 \\
{[0.16]^{* *}}\end{array}$ & $\begin{array}{l}-0.0041 \\
{[0.0037]}\end{array}$ & $\begin{array}{l}-0.0049 \\
{[0.0035]}\end{array}$ & $\begin{array}{c}0.75 \\
{[0.13]^{* *}}\end{array}$ & $\begin{array}{c}-0.0056 \\
{[0.0026]^{*}}\end{array}$ & $\begin{array}{l}-0.0052 \\
{[0.0027]}\end{array}$ \\
\hline$\frac{d y}{d P}$ & $\begin{array}{c}0.12 \\
{[0.032]^{* *}}\end{array}$ & $\begin{array}{l}-0.00082 \\
{[0.00073]}\end{array}$ & $\begin{array}{l}-0.00097 \\
{[0.00069]}\end{array}$ & $\begin{array}{c}0.15 \\
{[0.026]^{* *}}\end{array}$ & $\begin{array}{c}-0.0011 \\
{[0.00053]^{*}}\end{array}$ & $\begin{array}{c}-0.0010 \\
{[0.00055]}\end{array}$ \\
\hline $\begin{array}{l}\text { Effect relative to mean } \\
\text { Observations }\end{array}$ & $\begin{array}{c}0.045 \\
302786\end{array}$ & $\begin{array}{l}-0.0010 \\
302225\end{array}$ & $\begin{array}{c}0.040 \\
289473\end{array}$ & $\begin{array}{c}0.049 \\
496319\end{array}$ & $\begin{array}{l}-0.0014 \\
495527\end{array}$ & $\begin{array}{c}0.032 \\
477688\end{array}$ \\
\hline
\end{tabular}

Notes: Coefficients from RD regressions. Local linear regressions (different slopes) on each side of cutoff. Standard errors clustered on day level $(* \mathrm{P}<.05, * * \mathrm{P}<.01))$. 
Table A-7: Investigating Different Channels of Wage Losses

\begin{tabular}{|c|c|c|c|c|c|c|}
\hline & $\begin{array}{l}(1) \\
\text { Log Wage } \\
\text { Baseline }\end{array}$ & $\begin{array}{l}(2) \\
\text { Log Wage } \\
\text { Ctrls Obs }\end{array}$ & $\begin{array}{l}(3) \\
\text { Log Wage } \\
\text { Ctrls Obs }\end{array}$ & $\begin{array}{l}(4) \\
\text { Log Wage } \\
\text { Ctrls Obs }\end{array}$ & $\begin{array}{l}(5) \\
\text { Log Wage } \\
\text { Ctrls Obs }\end{array}$ & $\begin{array}{l}(6) \\
\text { Log Wage } \\
\text { Ctrls Obs }\end{array}$ \\
\hline \multicolumn{7}{|c|}{ Increase in Potential UI Dur. from 12 to 18 Months } \\
\hline $\mathrm{D}$ (Age above Cutoff) & $\begin{array}{l}-0.0066 \\
{[0.0029]^{*}}\end{array}$ & $\begin{array}{c}-0.0060 \\
{[0.0029]^{*}}\end{array}$ & $\begin{array}{c}-0.0074 \\
{[0.0030]^{*}}\end{array}$ & $\begin{array}{c}-0.0083 \\
{[0.0030]^{* *}}\end{array}$ & $\begin{array}{c}-0.0057 \\
{[0.0026]^{*}}\end{array}$ & $\begin{array}{l}-0.0046 \\
{[0.0026]}\end{array}$ \\
\hline $\begin{array}{l}\text { Switch } 3 \text { digit Industry after UE } \\
\text { Switch Occupation after UE }\end{array}$ & {$[0.0015]^{* *}$} & $\begin{array}{c}-0.035 \\
{[0.0018]^{* *}} \\
-0.091 \\
{[0.0017]^{* *}}\end{array}$ & & & & \\
\hline UR at start of unemployment spell & & & $\begin{array}{l}-0.015 \\
{[0.00077]^{* *}}\end{array}$ & & & \\
\hline UR at end of unemployment spell & & & {$[0.00081]^{* *}$} & & & \\
\hline Log Establishment Size of Post-UE Job & & & & $\begin{array}{c}0.036 \\
{[0.00043]^{* *}}\end{array}$ & & \\
\hline Post UE Spell: Fulltime Emp & & & & & $\begin{array}{c}0.61 \\
{[0.0024]^{* *}}\end{array}$ & \\
\hline Tenure at next job after UE & & & & & & $\begin{array}{c}0.012 \\
{[0.00012] * *}\end{array}$ \\
\hline$\frac{d y}{d P}$ & -0.0011 & -0.0010 & -0.0012 & -0.0014 & -0.00061 & -0.00053 \\
\hline & {$[0.00049]^{*}$} & {$[0.00049]^{*}$} & {$[0.00049]^{*}$} & {$[0.00049]^{* *}$} & {$[0.00044]$} & {$[0.00044]$} \\
\hline Observations & 437182 & 437182 & 437182 & 437182 & 437182 & 437182 \\
\hline Mean of Dep. Var. & 4.01 & 4.01 & 4.01 & 4.01 & 4.01 & 4.01 \\
\hline \multicolumn{7}{|c|}{ Pooling both Thresholds (12 to 18 Months and 18 to 22 Months) } \\
\hline D(Age above Cutoff) & $\begin{array}{l}-0.0039 \\
{[0.0021]}\end{array}$ & $\begin{array}{l}-0.0034 \\
{[0.0021]}\end{array}$ & $\begin{array}{c}-0.0050 \\
{[0.0021]^{*}}\end{array}$ & $\begin{array}{c}-0.0051 \\
{[0.0021]^{*}}\end{array}$ & $\begin{array}{c}-0.0044 \\
{[0.0019]^{*}}\end{array}$ & $\begin{array}{c}-0.0028 \\
{[0.0019]}\end{array}$ \\
\hline Switch 3 digit Industry after UE & -0.085 & $\begin{array}{l}-0.037 \\
{[0.0013] * *}\end{array}$ & & & & \\
\hline Switch Occupation after UE & & {$[0.0012]^{* *}$} & & & & \\
\hline UR at start of spell & & & $\begin{array}{c}-0.018 \\
{[0.00059]^{* *}}\end{array}$ & & & \\
\hline UR at end of unemployment spell & & & $\begin{array}{l}-0.0028 \\
{[0.00062]^{* *}}\end{array}$ & & & \\
\hline Log Establishment Size of Post-UE Job & & & & $\begin{array}{c}0.035 \\
{[0.00032]^{* *}}\end{array}$ & & \\
\hline Post UE Spell: Fulltime Emp & & & & & $\begin{array}{c}0.62 \\
{[0.0018]^{* *}}\end{array}$ & \\
\hline Tenure at next job after UE & & & & & & $\begin{array}{c}0.012 \\
{[0.000089]^{* *}}\end{array}$ \\
\hline$\frac{d y}{d P}$ & -0.00079 & -0.00069 & -0.0010 & -0.0010 & -0.00047 & -0.00037 \\
\hline Observations & $\begin{array}{c}{[0.00042]} \\
797752\end{array}$ & $\begin{array}{c}{[0.00042]} \\
797752\end{array}$ & $\begin{array}{c}{[0.00042]^{*}} \\
797752\end{array}$ & {$[0.00042]^{*}$} & {$[0.00038]$} & {$[0.00038]$} \\
\hline Mean of Dep. Var. & 4.02 & 4.02 & $\begin{array}{l}197 / 52 \\
4.02\end{array}$ & $\begin{array}{c}797752 \\
4.02\end{array}$ & $\begin{array}{l}797752 \\
4.02\end{array}$ & $\begin{array}{c}797752 \\
4.02\end{array}$ \\
\hline
\end{tabular}


Figure A-1: Quantile Regressions of the Effects of Extended Potential UI Durations on Reemployment Wages throughout the Spell of Non-employment

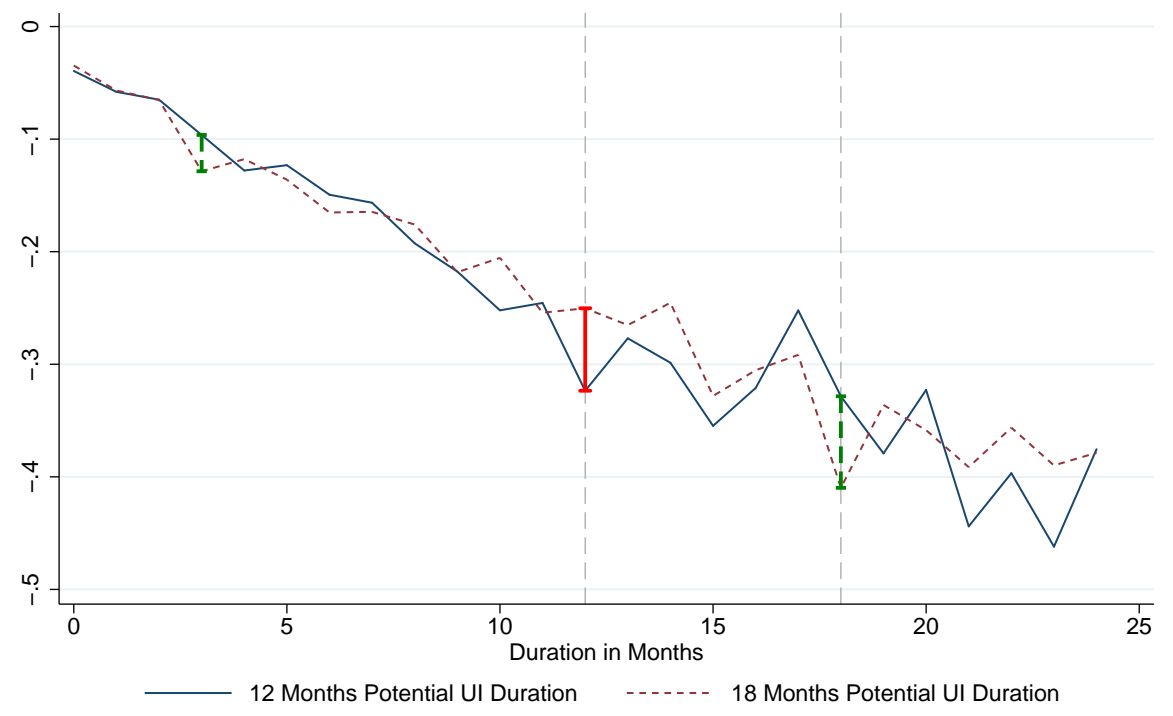

(a) Log wage difference (post - pre unemployment)

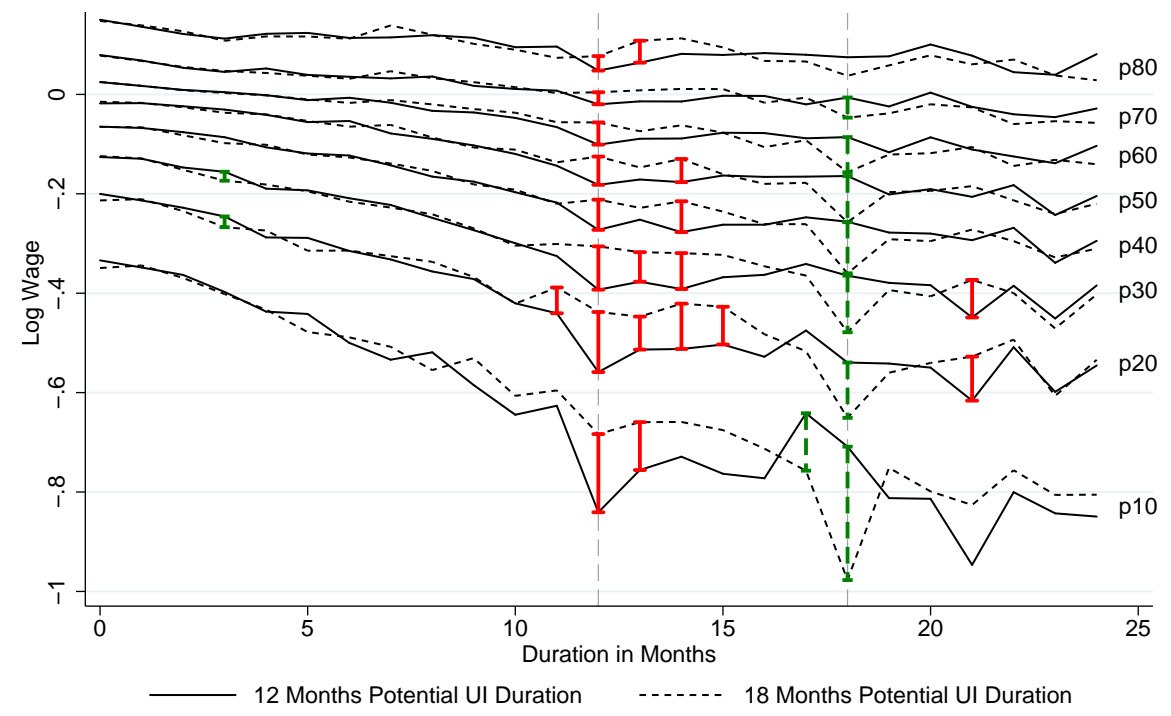

(b) Log wage difference (post - pre unemployment)

Notes: The difference between the lines is estimated point wise at each point of support using regression discontinuity estimation. Vertical bars indicate that the differences are statistically significant from each other at the five percent level. The sample are unemployed worker claiming UI between July 1987 and March 1999 who had worked for at least 36 months in the last 7 years without intermittent UI spell. The labels on the right indicate the percentiles at which the differences are estimated. For details see text. 